\section{EFFECT OF OHMIC HEATING AS A PRE- TREATMENT METHOD FOR BIODIESEL EXTRACTION FROM MICROALGAE}

Imam Sofi'ia*, Sumardi Hadi Sumarlan'b, Wignyantoc, Bambang Susilob

aDepartment of Agricultural Technology, Politeknik Negeri Lampung, 35144 Bandar Lampung, Indonesia bDepartment of Agricultural Engineering, Faculty of Agricultural Technology, Brawijaya University, 65145 Malang, Indonesia cDepartment of Agro-Industrial Technology, Faculty of Agricultural Technology, Brawijaya University, 65145 Malang, Indonesia
Article history

Received

3 October 2017

Received in revised form

18 February 2019

Accepted

19 February 2019

Published online

18 April 2019

*Corresponding author imam.sofii@polinela.ac.id
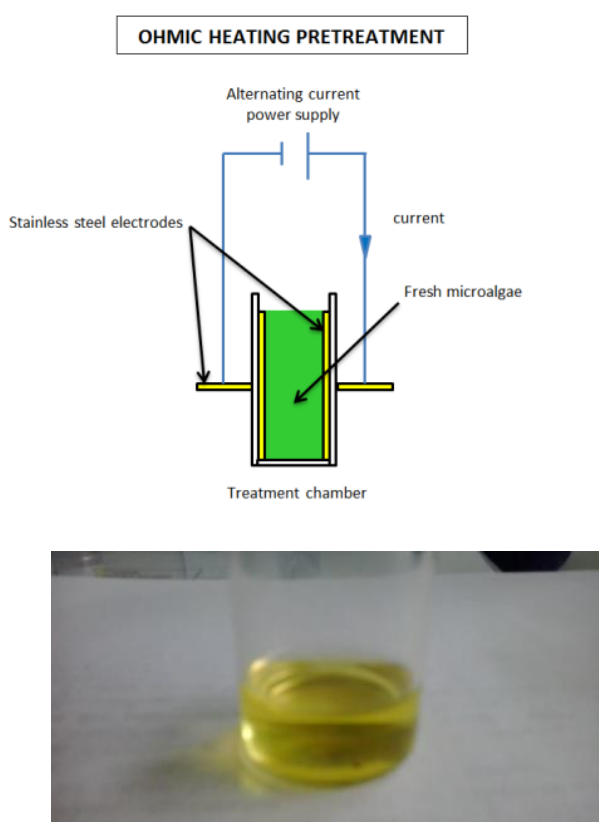

\begin{abstract}
Microalgae are single cell organisms that have the potential to be developed as feedstock for biodiesel oil. One of the problems of using microalgae as feedstock for biodiesel is in the extraction process. Microalgae extraction requires considerable cost. The purpose of this study was to determine the effect of ohmic heating as a method of pretreatment in microalgae oil extraction. The raw materials used were microalgae paste diluted in two levels cell density, 20 $\mathrm{g} / \mathrm{L}$, and $30 \mathrm{~g} / \mathrm{L}$. The pretreatment using alternating current (AC) electric with two voltage levels $(55 \mathrm{~V}$ and $110 \mathrm{~V}$ ), and the duration of pretreatment was 30 seconds and 60 seconds. The next step was drying and extracting microalgae by solvent extraction method of $n$-hexane. The results showed that the highest oil yields $(14.88 \%)$ were obtained by cell density treatment $20 \mathrm{~g} / \mathrm{L}$, done for 60 seconds of pretreatment and $110 \mathrm{~V}$ voltage. This result was higher than without pretreatment, so the use of pretreatment by ohmic heating can improve extracted oil yield than without pretreatment.
\end{abstract}

Keyword: Pretreatment, microalgae, ohmic heating

(c) 2019 Penerbit UTM Press. All rights reserved

\subsection{INTRODUCTION}

Microalgae are single-celled organisms that have considerable potential as sources of biodiesel feedstock. Microalgae include microscopic organisms that can perform photosynthesis. Microalgae can be found in marine and freshwater environments [1, 2], and have the ability to produce 1.83 tons of $\mathrm{CO}_{2}$ in the atmosphere when producing
1 ton of algae biomass [3]. Compared to other oilproducing plants, every hectare of microalgae in the waters can produce 10 to 100 times oil [1,4].

The use of microalgae as a fuel includes third generation biofuels that have advantages over the previous generation [5]. The advantages of microalgae as biodiesel feedstock are they: (a) can produce higher than food crop, (b) can grow on marginal land, (c) can utilise seawater and 
wastewater as culture medium, (d) can produce material burns that are non-toxic, biodegradable and renewable [6].

The process of making biodiesel from microalgae goes through several stages, i.e. cultivation, harvesting, drying, extraction, and esterification. The extraction stage is an important step to take the microalgae oil. This stage required a relatively expensive cost. In the case of biodiesel production using microalgae, $30-50 \%$ of the production cost for extraction activities includes cell disruption [7]. The greatest challenge to microalgae oil extraction is in the process of lysis or disruption of cells, so the cell contents are easy to remove. Oil is present in the lipid granules inside the cell.

The methods for the extraction of oil from microalgae can be done with mechanical or physically methods (oil expeller, microwave assisted extraction, ultrasonic assisted extraction) and chemically methods (Soxhlet extraction, supercritical fluid extraction, accelerated solvent extraction) [4]. Extraction results can physically remove the oil by about $75 \%$, while chemically removing $90-100 \%$ oils. Increased extraction results can be done by damaging cells or lysis. Various methods are being developed by researchers to improve the extraction results, e.g., chemical, mechanical, thermal or enzymatic. A combination of extraction using cell destruction will increase extraction efficiency [8-10].

Various methods of cell destruction continue to be developed such as high-pressure homogenizer $(\mathrm{HPH})[11,12]$, sonication $[13,14]$, microwave assisted extraction [15-17], osmotic shock $[8,18]$, solvent extraction [19-21], supercritical fluid extraction [22$24]$, and enzymatic $[25,26]$. Another method of microalgae cell destruction is high voltage electricity [27-35]. The use of high voltage electricity proved to help improve the extraction results.

From some literature has not been found pretreatment method using low voltage electricity to help oil extraction of microalgae. Pretreatment using low voltage electricity in the form of ohmic heating [36]. The purpose of this study was to determine the effect of ohmic heating as a method of pretreatment in microalgae oil extraction.

\subsection{METHODOLOGY}

\subsection{Materials and Methods}

The raw material used is fresh microalgae nannochloropsis sp. that obtained from the Lampung Sea Fisheries Management Center (BBPBL). Microalgae culture was done in open ponds, whereas the fertiliser was commercial fertiliser $N, P$, and $K$ with a specific ratio. The cell density of microalgae was $20 \mathrm{~g} / \mathrm{L}$ (D1) and $30 \mathrm{~g} / \mathrm{L}$ (D2). The diluent used was aquades. The solvent for extraction was n-hexane.
The equipment used was step down transformer 1000 W using State Electricity Company (PLN) power source. Pretreatment chamber used batch typed with acrylic material. The dimension of the pretreatment chamber was $5 \mathrm{~cm} \times 5 \mathrm{~cm} \times 3 \mathrm{~cm}$ with volume $75 \mathrm{~cm}^{3}$. The electrodes used were stainless steel with a thickness of $3 \mathrm{~mm}$, and dimensions of 5 $\mathrm{cm} \times 5 \mathrm{~cm}$. Measuring instrument used was a thermocouple, Avometer, conductivity meter, ampere meter, and stopwatch. Extraction equipment was extractor soxhlet, glassware, water bath, oven, digital analytic, rotary vacuum evaporator.

\subsection{Procedure}

Pretreatment was done by inserting fresh microalgae pasta with a determined cell density $(20 \mathrm{~g} / \mathrm{L}$ and 30 $\mathrm{g} / \mathrm{L}$ ) into the pretreatment chamber with volume 75 $\mathrm{cm}^{3}$. The next stage was exposure to voltage electricity (55 V and $110 \mathrm{~V}$ ) according to treatment. Duration of treatment was two levels, 30 seconds and 60 seconds. Each treatment was repeated three times.

After ohmic heating treatment, microalgae paste was dried and extracted with a chemical solvent. Chemical extraction used the Soxhlet method. The chemical solvent was n-hexane. The extraction resulted in an oil and $n$-hexane mixture. Separation of oil and $n$-hexane solvent was done using a rotary vacuum evaporator.

The principle of pretreatment work using ohmic heating was the microalgae paste in the treatment room was exposed to the flow of electricity from the positive electrode to the negative electrode which caused the cell to lysis. Lysis cells were due to electricity and heat [36, 37]. With the provision of pretreatment using ohmic heating, the contents of the cell became easy to remove

\subsection{RESULTS AND DISCUSSION}

\subsection{Oil Yield}

The yield of pretreatment oils using ohmic heating with microalgae cell density of $20 \mathrm{~g} / \mathrm{L}$ at two voltage levels and two levels of exposure duration is shown in Figure 1. As can be seen in Figure 1 the highest oil yield of $14.88 \%$ occurred at 60 seconds pretreatment and $110 \vee(D 1 T 2 \vee 5)$, and the lowest oil yield at 30second treatment and voltage $55 \mathrm{~V}$ (D1T1 V4).

Pretreatment ohmic heating at 30-second exposures (T1) between $55 \mathrm{~V}(\mathrm{~V} 4)$ and $110 \mathrm{~V}(\mathrm{~V} 5)$ showed different results. It was found that the greater voltage produced a greater yield. The same pattern occurred at 60 seconds of electrical exposure. Electrical voltage affected the recovery of microalgae oil. The higher voltage produced or electric field strength, the greater the yield [38].

The duration of electric field exposure affects the yield. At the same voltage level, longer electric field 
exposures produce greater yield. This increase in yield occurred to V4 and V5. In dilute microalgae, paste $(20 \mathrm{~g} / \mathrm{L})$ showed that the increase in voltage, and longer pretreatment enhanced the yield of microalgae oil.

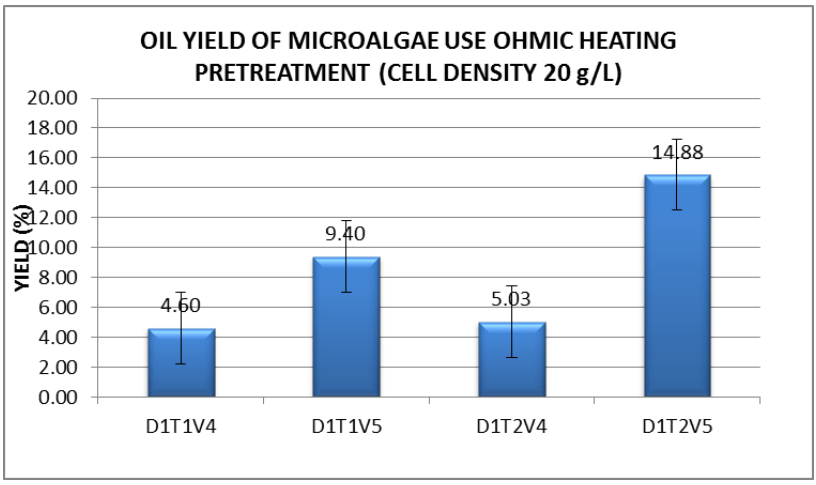

Figure 1 Effect of voltage and exposure duration an oil yield on pretreatment ohmic heating with a density of $20 \mathrm{~g} / \mathrm{L}$

Figure 2 shows the result of ohmic heating pretreatment for $30 \mathrm{~g} / \mathrm{L}$ cell density of microalgae. From Figure 2 it can be seen that the oil yield was influenced by voltage and duration of exposure. A 30-second exposure (T1) showed that an increase in voltage caused a decrease in oil yields. The same pattern also occurred for 60 seconds of exposure (T2). Based on Figure 2, at the same exposure duration, the oil yield is affected by electric voltage. The higher of voltage it will produce a lower lipid yield.

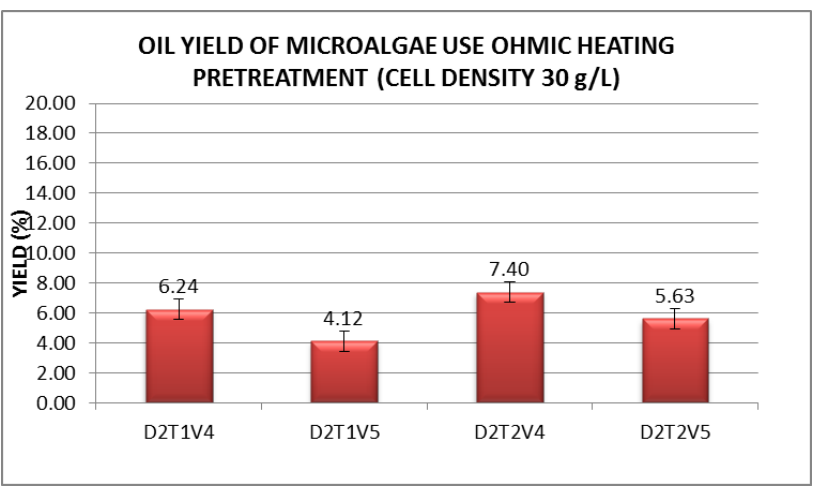

Figure 2 Effect of voltage and exposure duration on oil yield on ohmic heating pretreatment with a cell density of $30 \mathrm{~g} / \mathrm{L}$

Voltage treatment and pretreatment duration of microalgae paste with cell density between $20 \mathrm{~g} / \mathrm{L}$ and $30 \mathrm{~g} / \mathrm{L}$ produced different results (see Figures 1 and 2). Generally, $55 \mathrm{~V}$ and $110 \mathrm{~V}$ voltage with 30 seconds and 60-second exposure produced a higher yield of microalgae paste with a cell density of $20 \mathrm{~g} / \mathrm{L}$ (dilute) than microalga paste of $30 \mathrm{~g} / \mathrm{L}$ (more concentrated). In dilute paste, the highest yield was
$14.88 \%$, while in the more concentrated paste the highest yield was $7.40 \%$.

The yield of oil produced is influenced by dilution and voltage factors. In a dilute microalgae paste, the oil yield will increase if given a greater voltage but for a more concentrated paste it will be the opposite. This was related to the occurrence of electroporation or cell permeabilization in different cell density conditions [39]. Electroporation is affected by the conductivity of the solution. This means that solutions with lower conductivity required higher voltages, while those with higher conductivity required lower voltages [40].

As dilution affected the yield of microalgae oil, pretreatment using $55 \mathrm{~V}$ (low) and 30-second exposure ( $\mathrm{T} 1$ ) showed that the higher the microalgae cell density, the higher the yield (see Figure 3). In contrast, the use of $110 \mathrm{~V}$ with 30 -second exposure, higher microalgae cell density produced a lower yield. The same pattern occurred for 60 seconds of exposure (see Figure 4).

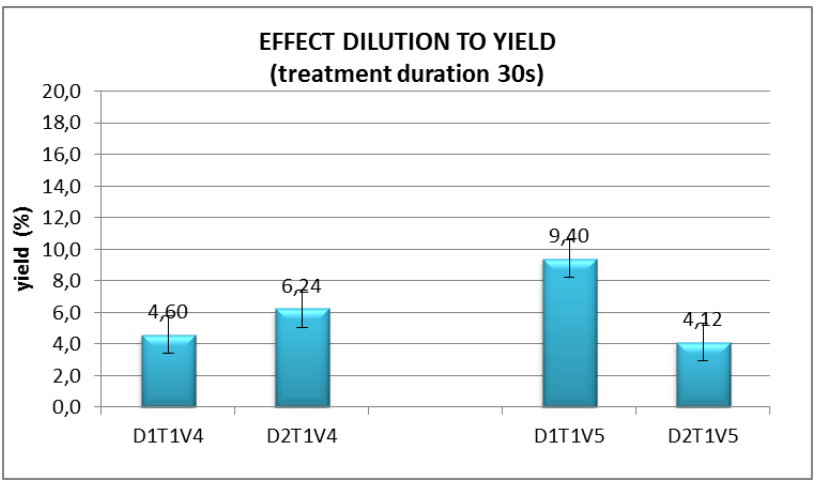

Figure 3 Effect of dilution and voltage an oil yield on ohmic heating pretreatment with 30 -second exposure duration

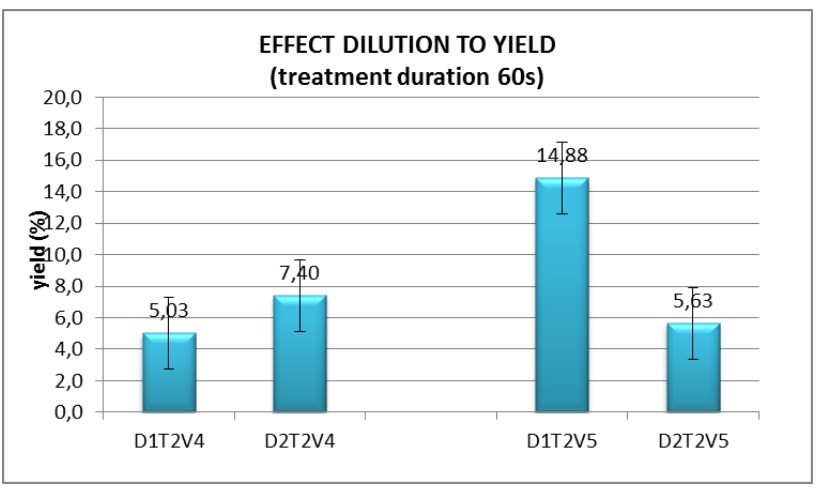

Figure 4 Effect of dilution and voltage on oil yield on ohmic heating pretreatment with 60-second exposure duration

Ohmic heating is heating that occurred due to the flow of electricity in materials that are an electrolyte. Heat occurred because of the movement of electricity. In the pretreatment of microalgae using ohmic heating, there was an increase in the temperature of the liquid. The 
temperature changes along with increased time due to exposure to electricity. Temperature change graph during the microalgae pretreatment process at $20 \mathrm{~g} / \mathrm{L}$ and $30 \mathrm{~g} / \mathrm{L}$ cell density with 60 seconds pretreatment is shown in Figure 5.

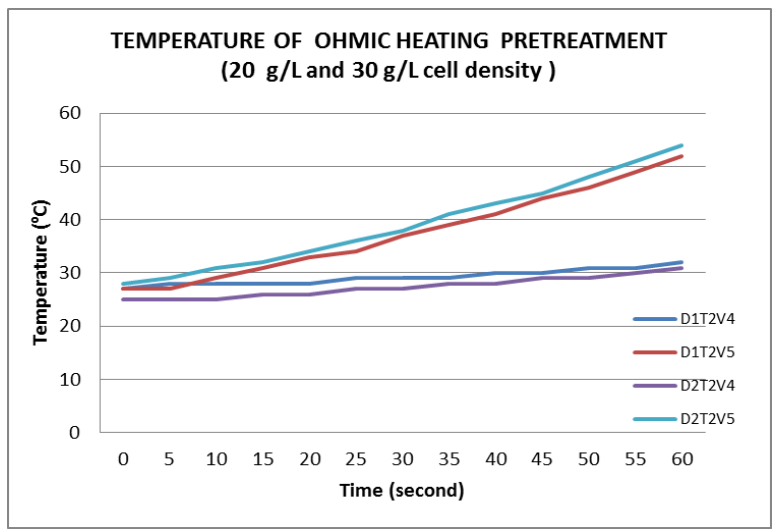

Figure 5 Temperature changes during ohmic heating pretreatment

Temperature changes in ohmic heating with 60 seconds pretreatment are shown in Figure 5. As can be seen in Figure 5, the longer pretreatment time resulted in an increase in temperature. A faster increase in temperature occurred at a higher voltage of $110 \mathrm{~V}(\mathrm{~V} 5)$. At a voltage of $55 \mathrm{~V}(\mathrm{~V} 4)$, the temperature increased more slowly. Cell density also influenced the rise in temperature. The cell density of $30 \mathrm{~g} / \mathrm{L}$ (D2) was greater than the cell density of $20 \mathrm{~g} / \mathrm{L}$ (D1). The higher the density of the cell; the faster the temperature increased.

\subsection{Pretreatment Energy}

The consumption of electrical energy during the pretreatment process was related to the amount of electric current flowing, and the voltage used during the pretreatment. Electric power is the multiplication of voltage, electrical current and time. The change in electric current during pretreatment ohmic heating is shown in Figure 6. The amount of electric current was influenced by the duration of pretreatment, the magnitude of the voltage, and the level of cell density.

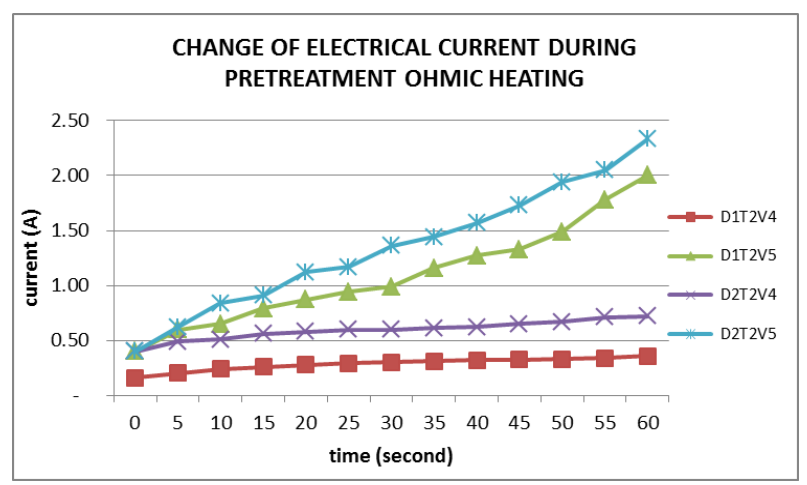

Figure 6 Development of electric current during pretreatment ohmic heating
During the ohmic heating process there was a change in temperature, which is a function of time. The longer duration of exposure will be increasing the temperature. These temperature changes will affect electric conductivity. The greater of electric conductivity then will result in a greater current electric. Thus, increased treatment time resulted in changes in temperature, conductivity, and electric current [41].

Changes in electric current were also influenced by electrical voltage and cell density. The greater voltage resulted in a greater current. Likewise, the more concentrated the solution, the greater the conductivity, which resulted in a greater electric current. The change in electric current was more dominantly influenced by the voltage than the cell density. In shown in Figure 7, most of the electric current changes occurred to the treatment of D2T2V5 (cell density $30 \mathrm{~g} / \mathrm{L}, 60$ second exposure time and voltage $110 \mathrm{~V})$.

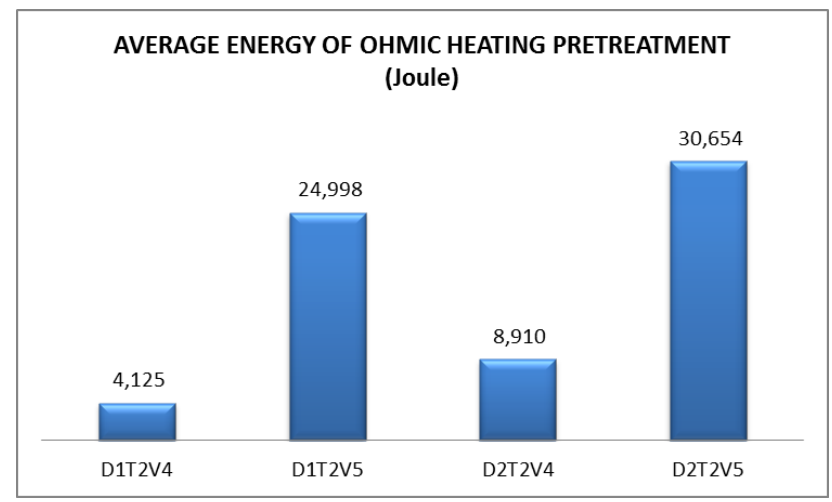

Figure $\mathbf{7}$ Electrical energy averaged 60 seconds pretreatment ohmic heating

The amount of electrical energy during pretreatment ohmic heating was affected by the voltage of electricity, electric current, and the duration of exposure. Figure 7 shows that the greatest energy requirement occurred to the treatment of D2T2V5 (30 g/L cell density, 60 second exposure time, and $110 \mathrm{~V}$ voltage) 30654 Joule, while the lowest electrical energy occurred to D1T2V4 treatment (20 $\mathrm{g} / \mathrm{L}$ cell density, exposure 60 seconds, and voltage 55 $\mathrm{V}$ ) of 4125 Joule. Electric energy is the multiplication of voltage, current, and exposure duration of electricity.

Table 1 Ratio of energy to yield during ohmic heating

\begin{tabular}{lrrr}
\hline Treatment & Energy(J) & Yield (\%) & Ratio \\
\hline DIT2V4 & 4125 & 5.03 & 820 \\
DIT2V5 & 24998 & 7.40 & 3378 \\
DIT2V5 & 8910 & 14.88 & 599 \\
D2T2V4 & 30654 & 5.63 & 5445 \\
\hline
\end{tabular}


In this study, the energy of pretreatment per percent of the yield of oil produced was done by looking at the energy ratio to yield (see Table 1). The lowest ratio was in the treatment of D2T2V4 of 599, which means that to produce $1 \%$ oil required pretreatment energy of $599 \mathrm{~J}$. The biggest ratio was in the treatment of D2T2V5 of 5445 which means that to produce $1 \%$ of oil needed energy $5445 \mathrm{~J}$. The low ratio indicates a more efficient use of energy to produce oil.

\subsection{Fatty Acid Composition}

The extracted nannochloropsis composition is known from the analysis using GC-MS (see Figure 8 and Table 2). The GC-MS analysis resulted in 31 different chemical compounds shown by the peak chromatogram. These compounds were short chain fatty acids up to long chains. The compounds may be used for various purposes including fuels, industry, cosmetics, pharmaceuticals, and foodstuff.

The GC-MS analysis showed that nannochloropsis is suitable as a biodiesel feedstock because it contains suitable fatty acids. Suitable fatty acids for fuel are myristic acid (C14: 0), palmitic acid (C16:0), palmitoleic acid (C16: 1), stearic acid (C18: 0), and oleic acid (C18: 1) [42]. Some fatty acids suitable for biodiesel are about $17 \%$ of the total fatty acid. It also contained other important chemical compounds as food and pharmaceuticals such as Docosahexaenoic acid (DHA) and Eicosapentaenoic acid (EPA).

CHROMATOGRAM RESULT of NANNOCHLOROPSIS SP

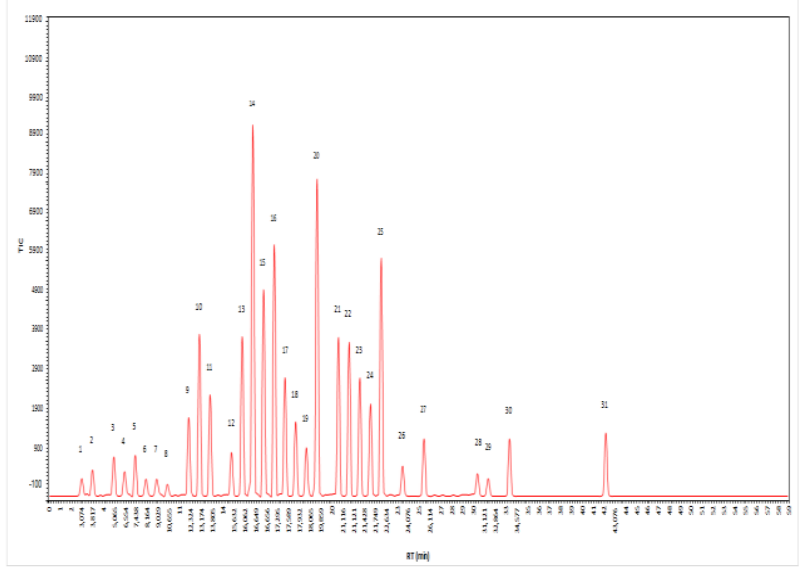

Figure 8 Chromatogram of GC-MS analysis results

Table 2 Fatty acid composition of nannochloropsis sp

\begin{tabular}{clc}
\hline No & Component & $\begin{array}{c}\text { Composition } \\
\text { (\%) }\end{array}$ \\
\hline 1 & Isovaleric acid & 0.56 \\
2 & Hexanoic acid & 0.84 \\
3 & Octanoic acid & 1.25 \\
\hline
\end{tabular}

\begin{tabular}{rlc}
\hline No & Component & $\begin{array}{c}\text { Composition } \\
\text { (\%) }\end{array}$ \\
\hline 4 & Nonanoic acid & 0.78 \\
5 & Decanoic acid & 1.30 \\
6 & Undecanoic acid & 0.54 \\
7 & Dodecanoic acid & 0.54 \\
8 & Tridecanoic acid & 0.38 \\
9 & Myristic acid & 2.51 \\
10 & Palmitoleic acid & 5.16 \\
11 & Palmitic acid & 3.24 \\
12 & Heptadecanoic acid & 1.39 \\
13 & Stearidonic acid & 5.09 \\
14 & a Linolenic acid & 11.84 \\
15 & y Linolenic acid & 6.58 \\
16 & Linolenic acid & 8.02 \\
17 & Oleic acid & 3.78 \\
18 & Octadecanoic acid & 2.37 \\
19 & Nonadecanoic acid & 1.55 \\
20 & Eicosapentaenoic acid & 10.11 \\
21 & Arachidonic acid & 5.06 \\
22 & Eicosatetraenoic acid & 4.91 \\
23 & Eicosadienoic acid & 3.77 \\
24 & Gondoic acid & 2.94 \\
25 & Docosahexaenoic acid & 7.59 \\
26 & Erucic acid & 0.96 \\
27 & Tetracosanoic acid & 1.82 \\
28 & B Sitosterol & y Tocopherol \\
\hline
\end{tabular}

\subsection{CONCLUSION}

The pretreatment method using ohmic heating can be used to help extract microalgae oil. Factors that influence ohmic heating pretreatment methods are electrical voltage, duration of treatment and cell density. During the pretreatment using ohmic heating, the temperature of the solution changes. 
The highest pretreatment efficiency occurred at $55 \mathrm{~V}$, for 60 seconds with a cell density of $20 \mathrm{~g} / \mathrm{L}$.

\section{Acknowledgement}

The authors would like to thank Brawijaya University and the Ministry of Technology and Higher Education of the Republic of Indonesia for funding assistance through the Domestic Postgraduate Scholarship (BPPDN) for this research activity.

\section{References}

[1] Demirbas, A. 2010. Use of Algae as Biofuel Sources. Energy Conversion and Management. 51: 2738-2749. https://doi:10.1016/j.enconman.2010.06.010.

[2] Brennan, L. and Owende, P. 2010. Biofuels from Microalgae: A Review of Technologies for Production, Processing, and Extractions of Biofuels and Co-products. Renewable and Sustainable Energy Reviews. 14: 557-577. https://doi.org/10.1016/j.rser.2009.10.009.

[3] Chisti, Y. 2008. Biodiesel from Microalgae Beats Bioethanol. Trends in Biotechnology. 26: 126-131.

https://doi.org/10.1016/j.biotechadv.2007.02.001.

[4] Mubarak, M., Shaija, A., and Suchithra, T. V. 2015. A Review on the Extraction of Lipid from Microalgae for Biodiesel Production. Algal Research 7: 117-123. https://doi.org/10.1016/j.algal.2014.10.008.

[5] Daroch, M., Geng, S., and Wang, G. 2013. Recent Advances in Liquid Biofuel Production from Algal Feedstocks. Applied Energy. 102: 1371-1381. https://doi.org/10.1016/j.apenergy.2012.07.031.

[6] Schenk, P. M., Thomas-Hall, S. R., Stephens, E., Marx, U. C. Mussgnug, J. H., Posten, C., Kruse, O., and Hankamer, B. 2008. Second Generation Biofuels: High-efficiency Microalgae for Biodiesel Production. BioEnergy Research. 1: 20-43. https://doi.org/10.1007/s12155-008-9008-8.

[7] Teixeira, R. E. 2012. Energy-efficient Extraction of Fuel and Chemical Feedstocks from Algae. Green Chemistry. 14(2): 419-427. https://10.1039/C2GC16225C.

[8] Lee, J. Y., Yoo, C., Jun, S. Y., Ahn, C. Y., and Oh, H. M. 2010. Comparison of Several Methods for Effective Lipid Extraction from Microalgae. Bioresource Technology. 101 S75-S77. https://doi.org/10.1016/j.biortech.2009.03.058.

[9] Prabakaran, P., and Ravindran, A. D. 2011. A Comparative Study on Effective Cell Disruptionmethods for Lipid Extraction from Microalgae. Letters in Applied Microbiology. 53(2): 150-154. https://doi.org/10.1111/j.1472-765X.2011.03082.x.

[10] Ranjan, A., Patil, C., and Moholkar, V. S. 2010. Mechanistic Assessment Ofmicroalgal Lipid Extraction. Industrial and Engineering Chemistry Research. 49(6): 2979-2985. https://doi.org/10.1021/ie9016557.

[11] Samarasinghe, N., Fernando, S., Lacey, R., and Faulkner, W. B. 2012. Algal Cell Rupture Using High Pressure Homogenization as a Prelude to Oil Extraction. Renewable Energy. 48: 300-308. https://doi.org/10.1016/j.renene.2012.04.039.

[12] Halim, R., Harun, R., Danquah, M. K., and Webley, P. A. 2012. Microalgal Cell Disruption for Biofuel Development, Applied Energy. 91 (1): 116-121. https://doi.org/10.1016/j.apenergy.2011.08.048.

[13] Lee, A. K., Lewis, D. M., and Ashman, P. J. 2012. Review Disruption of Microalgal Cells for the Extraction of Lipids for Biofuels: Processes and Specific Energy Requirements. Biomass and Bioenergy. 46: 89-101. https://doi.org/10.1016/j.biombioe.2012.06.034.
[14] Wang, M., Yuan, W., Jiang, X., Jing, Y., and Wang, Z. 2014. Disruption of Microalgal Cells Using High-frequency Focused Ultrasound. Bioresource Technology. 153: 315-321 https://doi.org/10.1016/j.biortech.2013.11.054.

[15] Biller, P., Friedman, C., and Ross, A. B. 2013. Hydrothermal Microwave Processing of Microalgae as a Pre-treatment and Extraction Technique for Bio-fuels and Bio-products. Bioresource Technology. 136: 188-195. https://doi.org/10.1016/j.biortech.2013.02.088.

[16] Cheng, J., Yu, T., Li, T., Zhou, J., and Cen, K. 2013. Using Wet Microalgae for Direct Biodiesel Production via Microwave Irradiation. Bioresource Technology. 131: 531535.

[17] Iabal, J., and Theegala, C. 2013. Microwave Assisted Lipid Extraction from Microalgae Using Biodiesel as Co-solvent. Algal Research. 2: 34-42. https://doi.org/10.1016/j.algal.2012.10.001.

[18] Yoo, G., Park, W. K., Kim, C. W., Choi, Y. E., and Yang, J. W. 2012. Direct Lipid Extraction from Wet Chlamydomonas Reinhardtii Biomass Using Osmotic Shock. Bioresource Technology. 123: 717-722. https://doi.org/10.1016/j.biortech.2012.07.102.

[19] Boyd, A. R., Champagne, P., McGinn, P. J., MacDougall, K. M., and Melanson, J. E. 2012. Switchable Hydrophilicity Solvents for Lipid Extraction from Microalgae for Biofuel Production. Bioresource Technology. 118: 628-632. https://doi.org/10.1016/j.biortech.2012.05.084.

[20] Balasubramanian, R. K., Doan, T. T. Y., and Obbard, J. P. 2013. Factors Affecting Cellular Lipid Extraction from Marine Microalgae. Chemical Engineering Journal. 215216: 929-936. https://doi.org/10.1016/j.cej.2012.11.063.

[21] Wahlen, B. D., Willis, R. M., and Seefeldt, L. C. 2011. Biodiesel Production by Simultaneous Extraction and Conversion of Total Lipids from Microalgae, Cyanobacteria, and Wild Mixed-Cultures. Bioresource Technology. 102: 2724-2730. https://doi.org/10.1016/j.biortech.2010.11.026.

[22] Cheng, C. H., Du, T. B., Pi, H. C., Jang, S. M., Lin, Y. H., and Lee, H. T. 2011 . Comparative Study of Lipid Extraction from Microalgae by Organic Solvent and Supercritical $\mathrm{CO} 2$ Bioresource Technology. 102: 10151-10153. https://doi.org/10.1016/j.biortech.201 1.08.064.

[23] Mouahid, A., Crampon, C., Toudji, S. A. A., and Badens, E., 2013. Supercritical CO2 Extraction of Neutral Lipids from Microalgae: Experiments and Modelling. Journal of Supercritical Fluids. 77: 7-16. http://dx.doi.org/10.1016/j.supflu.2013.01.024.

[24] Sovová, H. 2012. Steps of Supercritical Fluid Extraction of Natural Products and Their Characteristic Times. Journal of Supercritical Fluids. 66: 73-79. https://doi.org/10.1016/j.supflu.2011.11.004

[25] Horst, I., Parker, B. M., Dennis, J. S., Howe, C. J., Scott, S. A., Smith, A. G. 2012. Treatment of Phaeodactylum Tricornutum Cells with Papain Facilitates Lipid Extraction. Journal of Biotechnology. 162: 40-49. http://dx.doi.org/10.1016/j.jbiotec.2012.06.033

[26] Fu, C. C., Hung, T. C., Chen, J. Y., Su, C. H., and Wu, W. T. 2010. Hydrolysis of Microalgae Cell Walls for Production of Reducing Sugar and Lipid Extraction. Bioresource Technology. 101: 8750-8754 https://doi.org/10.1016/j.biortech.2010.06.100.

[27] Sofi'i, I., Sumarlan, S. H., Wignyanto, and Susilo, B. 2017. Combination of High Electric Voltage (Hev) and $\mathrm{NaCl}$ as Assisted Extraction Methods for Nannochloropsis sp. Boscience Research. 14(2): 386-394. http://doi.org/10.5281/zenodo.2557043.

[28] Flisar, K., Meglic, S. H., Morelj, J., Golob, J., and Miklavcic, D. 2014. Testing a Prototype Pulse Generator for a Continuous Flow System and Its Use for E. Coli Inactivation and Microalgae Lipid Extraction. Bioelectrochemistry. 100: 44-51. https://doi.org/10.1016/j.bioelechem.2014.03.008.

[29] Goettel, M., Eing, C., Gusbeth, C., Straessner, R., and Frey, W. 2013. Pulsed Electric Field Assisted Extraction of 
Intracellular Valuables from Microalgae. Algae Research. 2: $401-408$.

https://doi.org/10.1016/j.algal.2013.07.004.

[30] Foltz, G. 2012. Algae Lysis with Pulsed Electric Fields. Master Thesis, California State Polytechnic University, San Luis Obispo Follow.

[31] Kempkes, A. K., Roth, I., and Gaudreau, M. P. J. 2011. Pulsed Electric Field (PEF) Method for Continuous Enhanced Extraction of Oil and Lipids from Small Aquatic Plants. US Patent 2011/0107655 Al, 12 May 2011

[32] Lai, Y. S., Parameswaran, P., Li, A., M. Baez, and B. E. Rittmann. 2014. Effects of Pulsed Electric Field Treatment on Enhancing Lipid Recovery from the Microalga, Scenedesmus. Bioresource Technology. 173: 457-461. https://doi.org/10.1016/j.biortech.2014.09.124.

[33] Eing, C., Goettel, M., Straessner, R., Gusbeth, C., and Frey, W. 2013. Pulsed Electric Field Treatment of MicroalgaeBenefits for Microalgae Biomass Processing. IEEE Transactions on Plasma Science. 41 (10): 2901-2907. https://doi.org/10.1109/TPS.2013.2274805.

[34] Zbinden, M. D. A., Strum, B. S. M, Nord, R. D., Carey, W. J., Moore, D., Shinogle, H., and Stagg-Williams, S. M. 2013. Pulsed Electric Field (PEF) as an Intensification Pretreatment for Greener Solvent Lipid Extraction from Microalgae. Biotechnolology and Bioengineering. 110: 1605-1615. https://doi.org/10.1002/bit.24829

[35] Sheng, J., Vannela, R., and Rittmann, B. E. 2011 . Evaluation of cell-disruption effects of pulsed-electric-field treatment of Synechocystis PCC 680. Environmental Science \& Technology. 45:

3795-3802.
[36] Islam, M. S., Aryasomayajula, A., and Selvaganapathy, P. R. 2017. A Review on Macroscale and Microscale Cell Lysis Methods. Micromachines. 8: 83. DOI: $10.3390 / \mathrm{mi} 8030083$

[37] He, Z., and Lin, J.-M. 2018. Recent Developmnet of Cell Analysis on Microfluidics (Chapter 2) in Cell Analysis on Microfluidics. Integrated Analytical System. ISSN 2196-4483 (electronic), ISBN 978-981-10-5394-8 (eBook). https://doi.org/10.1007/978-981-10-5394-8.

[38] Lakkakula, N., Lima, M., and Walker, T. 2004. Rice Bran Stabilization and Rice Bran Oil Extraction using Ohmic Heating. Journal of Bioresource Technology. 92: 157-161. https://doi.org/10.1016/j.biortech.2003.08.010.

[39] Pucihar, G., Kotnik, T., Kanduser, M., and Miklavcic, D. 2001. The Influence of Medium Conductivity on Electropermeabilization and Survival of Cells in Vitro. Bioelectrochemistry. 54: 107-115. https://doi.org/10.1016/S1567-5394(01)00117-7.

[40] Ivorra. A., Villemejanebcd, J., and Mir, L. M. 2010 Electrical Modeling of the Influence of Medium Conductivity on Electroporation. Physical Chemistry Chemical Physics. 12: 10055-10064. DOI: 10.1039/c004419a.

[41] Icier. F., and llicali, C. 2005. Temperature Dependent Electrical Conductivities of Fruit Purees during Ohmic Heating. Food Research International. 38: 1135-1142. https://doi.org/10.1016/j.foodres.2005.04.003.

[42] Olofsson. M., Lamela, T., Nilsson, E., Bergé, J. P. I., Pino, V. del, Uronen, P., and Legrand, C. 2012. Seasonal Variation of Lipids and Fatty Acids of the Microalgae Nannochloropsis oculata Grown in Outdoor Large-Scale Photobioreactors. Energies. 5(5): 1577-1592. https://doi.org/10.3390/en5051577. 